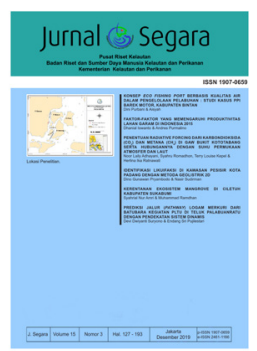

JURNAL SEGARA

http://ejournal-balitbang.kkp.go.id/index.php/segara

ISSN : 1907-0659

e-ISSN : 2461-1166

Nomor Akreditasi: 766/AU3/P2MI-LIPI/10/2016

\title{
KERENTANAN EKOSISTEM MANGROVE DI CILETUH KABUPATEN SUKABUMI
}

\section{MANGROVE ECOSYSTEM VULNERABILITY IN CILETUH SUKABUMI DISTRICT}

\author{
Syahrial Nur Amri \& Muhammad Ramdhan \\ Pusat Riset Kelautan, BRSDM - KKP \\ Jln. Pasir Putih 1 Ancol Jakarta; Telp/fax : +62 2164711583
}

Diterima: 1 Maret 2018; Diterima Setelah Perbaikan: 9 Desember 2019; Disetujui Terbit: 15 Desember 2019

\begin{abstract}
ABSTRAK
Ekosistem mangrove merupakan salah satu ekosistem pesisir yang mengalami dampak perubahan akibat terjadinya perubahan iklim dan aktifitas manusia. Tumbuhan mangrove memiliki kemampuan khusus untuk beradaptasi dengan kondisi lingkungan yang ekstrim, seperti kondisi tanah yang tergenang, kadar garam yang tinggi serta kondisi tanah yang kurang stabil. Penelitian ini dilakukan di kawasan Ciletuh Kabupaten Sukabumi. Untuk melihat indeks kerentanan mangrove, terdapat dua kondisi atau spot mangrove yang dibandingkan, yaitu ekosistem mangrove di Sungai Ciletuh, dan ekosistem mangrove di kawasan ekowisata Manrajaya yang dikelola oleh masyarakat seluas 9 hektar. Data dikumpulkan melalui pengukuran langsung di lapangan, wawancara dengan teknik pertanyaan terstruktur, dan pengolahan citra satelit. Hasil yang diperoleh menunjukkan bahwa ekosistem mangrove Sungai Ciletuh memiliki nilai sensitifitas sebesar 2,17 dan nilai adaptif kapasitas sebesar 2,32 yang berarti memiliki tingkat kerentanan menengah tengah. Sedangkan untuk ekosistem mangrove Manrajaya memiliki nilai sensitifitas sebesar 1,77 dan nilai Adaptif Kapasitas sebesar 1,46 yang berarti memiliki tingkat kerentanan menengah rendah.
\end{abstract}

Kata Kunci: Indeks Kerentanan, Indeks Nilai Penting, Ekosistem Mangrove, Kabupaten Sukabumi.

\section{ABSTRACT}

Mangrove is one of the coastal ecosystems that is experiencing the effects to climate change and human activities. Mangrove plants have a special ability to adapt to extreme environmental conditions, such as stagnant soil conditions, high salinity and unstable soil conditions. This research was conducted in the Ciletuh area of Sukabumi Regency. To see the mangrove vulnerability index, there are two conditions or mangrove spots that are compared, namely the mangrove ecosystem in the Ciletuh River, and the mangrove ecosystem in the Manrajaya ecotourism area which is managed by a 9 hectare community. Data was collected through direct measurements in the field, interviews with question and answer techniques, and satellite image processing. The results obtained indicate that the Ciletuh River mangrove ecosystem has a sensitivity value of 2.17 and an adaptive capacity value of 2.32 which means it has a medium - medium level of vulnerability. As for the Manrajaya mangrove ecosystem it has a sensitivity value of 1.77 and an Adaptive Capacity value of 1.46 which means it has a mediumlow vulnerability level.

Keywords: Vulnerability Index, Important Value Index, Mangrove Ecosystem, Sukabumi District.

Corresponding author:

Jl. Pasir Putih I Ancol Timur, Jakarta Utara 14430. Email: m.ramdhan@kkp.go.id 


\section{PENDAHULUAN}

Ekosistem mangrove merupakan komunitas vegetasi pantai tropis yang didominasi oleh beberapa jenis pohon mangrove yang tumbuh dan berkembang pada daerah pasang surut pantai berlumpur (Bengen, 2001). Ekosistem mangrove merupakan salah satu ekosistem pesisir yang mengalami dampak perubahan akibat terjadinya perubahan iklim dan aktifitas manusia. Mangrove merupakan suatu formasi hutan yang tumbuh di daerah pasang surut, lantai hutannya tergenang pada saat pasang dan bebas dari genangan pada saat surut (Supriharyono, 2009; Kusmana, 2007) Ekosistem mangrove merupakan ekosistem interface antara ekosistem daratan dengan ekosistem lautan. Oleh karena itu, ekosistem ini mempunyai fungsi yang spesifik yang keberlangsungannya bergantung pada dinamika yang terjadi di ekosistem daratan dan lautan (Kusmana, 2007). Ekosistem mangrove merupakan salah satu ekosistem yang mempunyai produktivitas yang tinggi yang memproduksi sumber makanan untuk sebagian besar berbagai jenis ikan, udang, kepiting dan berbagai biota perairan pantai lainnya. Selain itu dari segi perikanan, mangrove juga berperan sebagai spawning dan nursery grounds (Kariada \& Andin, 2014; Djohan, 2007). Kesemua fungsi mangrove tersebut tetap ada selama vegetasi mangrove dapat dipertahankan keberadaannya (Kusmana, 2007). Ekosistem mangrove adalah pendukung berbagai jasa ekosistem di sepanjang garis pantai di kawasan tropis (Donato et al, 2012).Sebagai obyek daya tarik wisata alam dan atraksi ekowisata (Sudiarta, 2006; Wiharyanto \& Laga, 2010) dan sebagai sumber tanaman obat (Supriyanto et al., 2014).

Menurut Saparinto (2007), saat ini sebagian besar kawasan mangrove berada dalam kondisi rusak, bahkan di beberapa daerah kondisinya sangat memprihatinkan. Tercatat laju degradasi mangrove mencapai 160-200 ribu ha/tahun. Untuk mengatasi hal tersebut, pemerintah Indonesia giat untuk melakukan program rehabilitasi hutan mangrove. Dampak yang ditimbulkan dengan adanya rehabilitasi hutan mangrove antara lain meningkatnya produksi garam/ ikan, mengurangi abrasi pantai, menahantiupan angin dari laut ke darat, semakin banyak tangkapan biota (udang, kepiting, kerang) di pesisir, dan menjadikan kawasan tersebut menjadi daerah objek wisata (Utomo et al., 2017).

Tumbuhan mangrove memiliki kemampuan khusus untuk beradaptasi dengan kondisi lingkungan yang ekstrim, seperti kondisi tanah yang tergenang, kadar garam yang tinggi serta kondisi tanah yang kurang stabil. Dengan kondisi lingkungan seperti itu, beberapa jenis mangrove mengembangkan mekanisme yang memungkinkan secara aktif mengeluarkan garam dari jaringan, sementara yang lainnya mengembangkan sistem akar napas untuk membantu memperoleh oksigen bagi sistem perakarannya. Dalam hal lain, beberapa jenis mangrove berkembang dengan buah yang sudah berkecambah sewaktu masih di pohon induknya (vivipar), seperti Kandelia, Bruguiera, Ceriops dan Rhizophora (Noor et al., 1999).

Mangrove merupakan sumber daya yang dapat dipulihkan (renewable resources) yang menyediakan berbagai jenis produk (produk langsung dan produk tidak langsung) dan pelayanan lindungan lingkungan seperti proteksi terhadap abrasi, pengendali intrusi air laut, mengurangi tiupan angin kencang, mengurangi tinggi dan kecepatan arus gelombang, rekreasi dan pembersih air dari polutan (Kusmana, 2007; Wahyudi et al., 2014). Manfaat ekosistem mangrove yang berhubungan dengan fungsi fisik adalah sebagai mitigasi bencana seperti peredam gelombang dan angin badai bagi daerah yang ada di belakangnya, pelindung pantai dari abrasi, gelombang air pasang (rob), tsunami, penahan lumpur dan perangkap sedimen yang diangkut oleh aliran air permukaan, pencegah intrusi air laut ke daratan, serta dapat menjadi penetralisir pencemaran perairan pada batas tertentu (Lasibani \& Eni, 2009).

Dalam hal struktur, mangrove di Indonesia lebih bervariasi bila dibandingkan dengan daerah lainnya. Dapat ditemukan mulai dari tegakan Avicennia marina dengan ketinggian 1 - 2 meter pada pantai yang tergenang air laut, hingga tegakan campuran BruguieraRhizophora-Ceriops dengan ketinggian lebih dari 30 meter (misalnya, di Sulawesi Selatan). Di daerah pantai yang terbuka, dapat ditemukan Sonneratia albadan Avicennia alba, sementara itu di sepanjang sungai yang memiliki kadar salinitas yang lebih rendah umumnya ditemukan Nypa fruticans dan Sonneratia caseolaris. Umumnya tegakan mangrove jarang ditemukan yang rendah kecuali mangrove anakan dan beberapa jenis semak seperti Acanthus ilicifolius dan Acrostichum aureum. Di Indonesia tercatat setidaknya 202 jenis tumbuhan mangrove, meliputi 89 jenis pohon, 5 jenis palma, 19 jenis pemanjat, 44 jenis herba tanah, 44 jenis epifit dan 1 jenis paku. Dari 202 jenis tersebut, 43 jenis (diantaranya 33 jenis pohon dan beberapa jenis perdu) ditemukan sebagai mangrove sejati (true mangrove), sementara jenis lain ditemukan disekitar mangrove dan dikenal sebagai jenis mangrove ikutan (asociate asociate) (Noor et al., 1999). Di seluruh dunia, Saenger et al. (1983) mencatat sebanyak 60 jenis tumbuhan mangrove sejati. Dengan demikian terlihat bahwa Indonesia memiliki keragaman jenis yang tinggi.

Kerentanan adalah keadaan atau kondisi yang dapat mengurangi kemampuan suatu objek untuk menghadapi bahaya atau ancaman bencana (Ramdhan et al., 2012). Objek yang dimaksud dalam 
penelitian ini adalah ekosistem mangrove. Tujuan penelitian ini adalah mengukur tingkat kerentanan ekosistem mangrove di muara Sungai Ciletuh Kabupaten Sukabumi.

\section{METODE PENELITIAN}

\section{Lokasi}

Penelitian dilakukan di kawasan Ciletuh Kabupaten Sukabumi (Gambar 1). Untuk melihat indeks kerentanan mangrove, terdapat dua kondisi atau spot mangrove yang dibandingkan, yaitu ekosistem mangrove di Sungai Ciletuh, dan ekosistem mangrove Manrajaya di kawasan ekowisata mangrove yang dikelola oleh masyarakat seluas 9 hektar.

\section{Teknik Pengambilan Data}

Data dikumpulkan melalui pengukuran langsung di lapangan dan wawancara dengat teknik snowball sampling pada stake holder yang ditemui di lapangan, adapun profil responden yang diperoleh adalah 1 orang pengelola mangrove dan 5 orang nelayan setempat.

\section{Indeks Nilai Penting}

Kondisi mangrove direpresentasikan dengan kondisi kerapatan jenis (Di), kerapatan relative jenis (RDi), frekuensi jenis $(\mathrm{Fi})$, frekuensi relative jenis (RFi) dan nilai penting jenis (INP) mangrove yang ada di lokasi (Odum, 1971). Perhitungannya adalah sebagai berikut :

Kerapatan jenis (Di) adalah jumlah tegakan jenis i dalam suatu unit area

$$
\mathrm{Di}=\mathrm{ni} / \mathrm{A}
$$

di mana,

Di : kerapatan jenis i

ni : jumlah total tegakan jenis $i$

A :luas total area pengambilan sampel (luas total plot)

Kerapatan relatif jenis (RDi) adalah perbandingan antara jumlah tegakan jenis i (ni) dan jumlah total tegakan seluruh jenis $\left(\sum n\right)$

$$
\mathrm{RDi}=\left(\mathrm{ni} / \sum \mathrm{n}\right) \times 100
$$

di mana,

Rdi : kerapatan jenis i

$\sum \mathrm{n}$ : jumlah seluruh tegakan

Frekuensi jenis (Fi) adalah peluang ditemukannya jenis i dalam petak contoh/ plot yang diamati

$$
\mathrm{Fi}=\mathrm{pi} /(\Sigma \mathrm{p})
$$

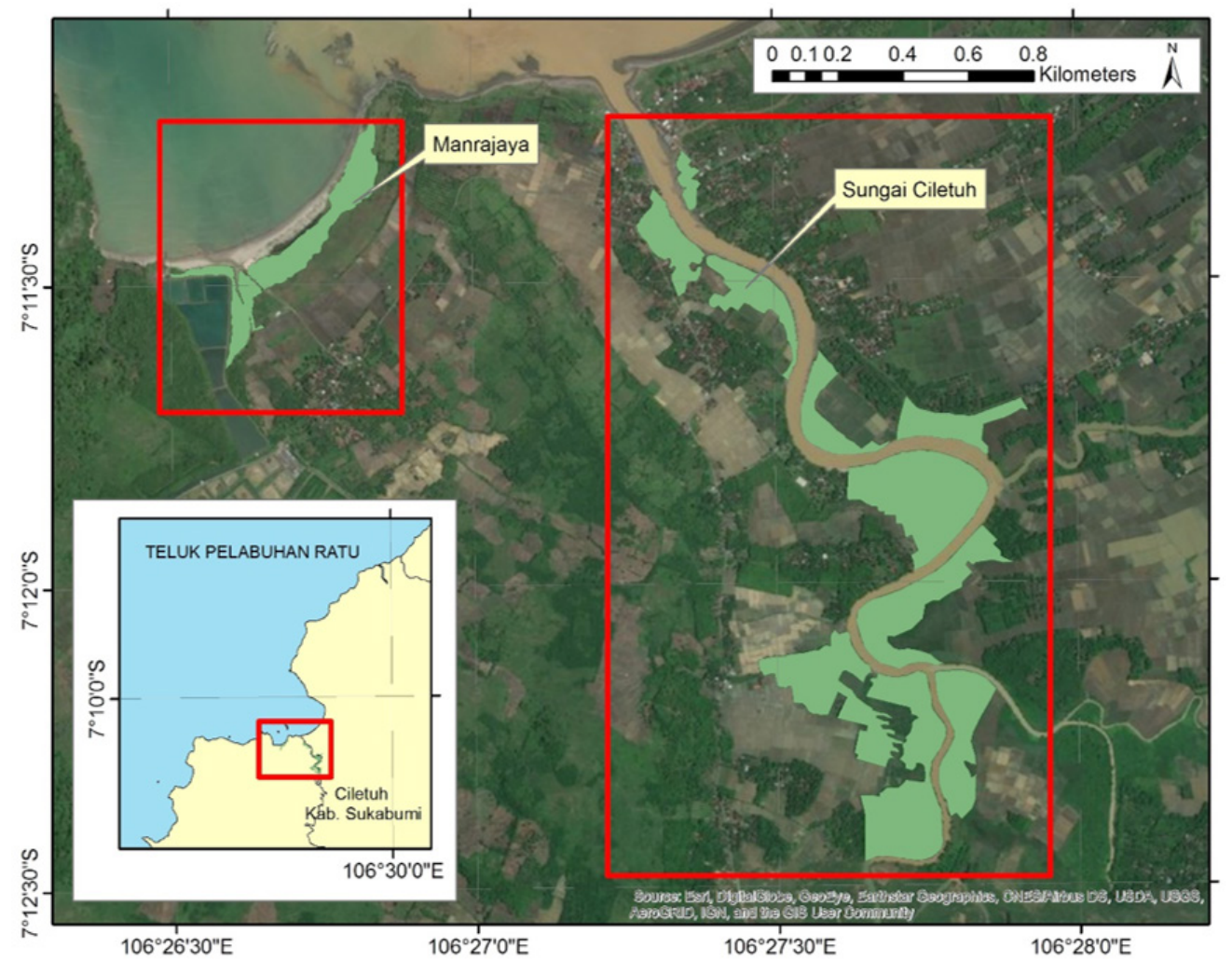

Gambar 1. Lokasi Penelitian. 
pi : jumlah petak ditemukan jenis i

$\Sigma p$ : jumlah petak pengamatan

Frekuensi relatif jenis (RFi) adalah perbandingan antara frekuensi jenis i (Fi) dan jumlah frekuensi sekuruh jenis $(\Sigma F)$.

$$
\mathrm{RFi}=\left(\mathrm{Fi} / \sum \mathrm{F}\right) \times 100
$$

di mana,

$$
\begin{array}{ll}
\mathrm{RFi} & : \text { frekuensi relatif jenis i } \\
\Sigma \mathrm{F} & : \text { frekuensi seluruh jenis }
\end{array}
$$

Penutupan jenis $(\mathrm{Ci})$ adalah perbandingan basal area jenis terhadap luasan unit area.

$$
\mathrm{Ci}=\left(\sum \mathrm{BA}\right) / \mathrm{A}
$$

di mana,

$\mathrm{Ci}:$ Penutupan jenis ke-i

$\mathrm{BA}:$ basal area $=\pi \mathrm{d} 2 / 4$

Penutupan relatif $(\mathrm{RCi})$ adalah perbandingan penutupan jenis ke-i dengan total penutupan seluruh jenis.

$$
\mathrm{RCi}=\left(\mathrm{Ci} /\left(\sum \mathrm{C}\right)\right) \times 100
$$

di mana,

$$
\begin{array}{ll}
\mathrm{RCi} & : \text { penutupan relatif } \\
\mathrm{EC} & : \text { penutupan total untuk seluruh jenis }
\end{array}
$$

Indeks Nilai Penting (INP) menggambarkan kedudukan ekologis suatu jenis dalam komunitas dengan melihat dominasi suatu jenis terhadap jenis lainnya. Nilai indeks ini berkisar antara 0 - 300 atau 1-3.

$$
I N P=R D i+R F i+R C i
$$

\section{Indeks Kerentanan}

Indeks kerentanan merupakan tanda (signal) yang mengukur, menyederhanakan, dan mengkomunikasikan realita yang kompleks dari suatu kondisi (Farell \& Hart 1998). Indeks ini sangat berguna karena dapat membantu dalam menentukan target dan standar untuk memantau perubahan dan membandingkan entitas yang berbeda dalam hal tempat dan waktu. Indeks dapat juga digunakan sebagai basis modal alokasi sumber daya. Global Environment Facility (GEF), suatu lembaga internasional yang bergerak di bidang lingkungan hidup, juga mengembangkan indeks kerentanan untuk menentukan alokasi pembiayaan di beberapa negara berkembang. Indeks dapat digunakan sebagai alat 'adaptive management' menilai keberhasilan pemantauan dalam mencapai tujuan pembangunan berkelanjutan (SOPAC, 2005). Indeks umumnya melibatkan sejumlah indikator untuk menghasilkan sebuah indeks tunggal (Bossel, 1999). Untuk menghasilkan sebuah indeks tunggal, keragaan data dan indikator perlu distandarisasi dalam suatu unit yang sama. Hal ini banyak dilakukan dengan mereduksi seluruh komponen ke suatu nilai skoring pada beberapa skala.

Menurut Turner et al. (2003) kerentanan merupakan suatu fungsi overlay dari ketersingkapan (exposure), sensitivitas (sensitivity), dan kapasitas atau kemampuan adaptif (adaptivecapacity). Sedangkan menurut UNISDR (2005) kerentanan sebagai kondisi-kondisi yang ditentukan oleh faktorfaktor atau proses-proses fisik, sosial, ekonomi dan lingkungan, yang bisa meningkatkan rawannya sebuah komunitas terhadap dampak bahaya.

Indeks kerentanan mengadopsi dan memodifikasi indeks kerentanan yang dikembangkan oleh MERF (2013). Area Sungai Cilteuh dapat digunakan sebagai pembanding nilai kerentanan dari Manrajaya, dimana kondisi mangrove di Sungai Ciletuh sangat dipengaruhi oleh kondisi hidrogeografi Sungai Ciletuh.

\section{Tahapan}

Terdapat 8 (delapan) tahapan yang dilakukan dalam menyusun kajian kerentanan tersebut sebagaimana dinyatakan oleh Schroter et al. (2005), antara lain:

1. Mendefinisikan wilayah studi, baik secara spasial maupun temporal

2. Mencari dan mengumpulkan informasi terkait dengan wilayah studi, melalui kajian literatur dan diskusi dengan peneliti sebelumnya;

3. Mengembangkan hipotesis siapa/apa yang mengalami kerentanan;

4. Mengembangkan model kerentanan dengan menguraikan ketersingkapan, sensitivitas, dan kapasitas adaptif, mengidentifikasi factor pendorong;

5. Menentukan indikator untuk elemen kerentanan, seperti ketersingkapan, sensitivitas, dan kapasitas adaptif;

6. Mengoperasikan model kerentanan, melalui pembobotan dan penggabungan indikator, validasi hasil;

7. Pengembangan lebih lanjut dengan memilih skenario dan aplikasi model; dan

8. Mengkomunikasikan hasil kajian kerentanan kepada stakeholder.

\section{Kriteria/Variabel Indeks dan Pembobotan}

Kriteria yang ditanyakan untuk pengukuran sensitifitas lahan mangrove dan kapasitas adaptifnya dapat dilihat dalam Tabel 1 dan Tabel 2.

Skor diberikan pada masing-masing kriteria dengan nilai seperti dalam Tabel 3. Nilai rendah memiliki skor 1-2, nilai menengah 3-4 dan nilai tertinggi adalah 5 . 
Tabel 1.

Kriteria untuk pengukuran sensitifitas

\begin{tabular}{|c|c|c|c|}
\hline Sensitifitas & Kriteria & No & Sub-Kriteria \\
\hline \multirow[t]{9}{*}{ Habitat Mangrove } & \multirow[t]{2}{*}{ Sebaran dan Jenis } & 1 & $\begin{array}{l}\text { Seberapa banyak area mangrove alami } \\
\text { yang masih tersisa? }\end{array}$ \\
\hline & & 2 & Jenis mangrove apa yang masih tersedia \\
\hline & \multirow[t]{3}{*}{$\begin{array}{l}\text { Kesehatan hutan } \\
\text { mangrove }\end{array}$} & 3 & $\begin{array}{l}\text { Apakah spesies yang lambat tumbuh, } \\
\text { lambat berkolonialisasi, umum dijumpai } \\
\text { di lokasi }\end{array}$ \\
\hline & & 4 & $\begin{array}{l}\text { Apakah lebih banyak sebaran pohon-pohon } \\
\text { berukuran besar dibandingkan yang } \\
\text { berukuran kecil (dalam hal kepadatan)? }\end{array}$ \\
\hline & & 5 & $\begin{array}{l}\text { Adakah akumulasi sampah padat di area } \\
\text { mangrove? }\end{array}$ \\
\hline & \multirow[t]{4}{*}{ Parameter Bio-Fisik } & 6 & Salinitas \\
\hline & & 7 & Substrat \\
\hline & & 8 & Lama waktu genangan pasut (bulan) \\
\hline & & 9 & Tinggi genangan pasut maksimum (m) \\
\hline \multirow[t]{5}{*}{ Sektor Perikanan } & \multirow[t]{3}{*}{$\begin{array}{l}\text { Jenis perikanan apa } \\
\text { yang beroperasi? }\end{array}$} & 11 & $\begin{array}{l}\text { Dominasi jenis ikan tangkapan di wilayah } \\
\text { sekitar perairan mangrove }\end{array}$ \\
\hline & & 12 & Laju Penangkapan \\
\hline & & 13 & $\begin{array}{l}\text { Apakah ada pembatasan peralatan } \\
\text { penangkapan ikan di habitat mangrove? }\end{array}$ \\
\hline & Seberapa penting & 14 & Kepadatan Penduduk \\
\hline & $\begin{array}{l}\text { kegiatan perikanan } \\
\text { terhadap komunitas } \\
\text { masyarakat }\end{array}$ & 15 & $\begin{array}{l}\text { Ketergantungan masyarakat } \\
\text { perikanan terhadap ekosistem } \\
\text { mangrove }\end{array}$ \\
\hline
\end{tabular}

Tabel 2.

Kriteria untuk pengukuran kapasitas adaptif

\begin{tabular}{|c|c|c|c|}
\hline Adaptif Capacity & Kriteria & No & Sub-Kriteria \\
\hline \multirow[t]{5}{*}{$\begin{array}{l}\text { Tingkat Pengelolaan } \\
\text { Mangrove }\end{array}$} & $\begin{array}{l}\text { Upaya pemulihan } \\
\text { habitat }\end{array}$ & 1 & $\begin{array}{l}\text { Seberapa banyak area yang terdegradasi } \\
\text { yang masih harus direhabilitasi? }\end{array}$ \\
\hline & $\begin{array}{l}\text { Tingkat Pemanfaatan } \\
\text { Mangrove }\end{array}$ & 2 & $\begin{array}{l}\text { Apakah sudah ada pengembangan hutan } \\
\text { mangrove berbasis ekowisata }\end{array}$ \\
\hline & $\begin{array}{l}\text { Penetapan Kawasan } \\
\text { Konservasi Mangrove }\end{array}$ & 3 & $\begin{array}{l}\text { Seberapa besar kebutuhan untuk } \\
\text { memperluas kawasan konservasi? }\end{array}$ \\
\hline & & 4 & $\begin{array}{l}\text { Apakah desain \& pengelolaan kawasan } \\
\text { konservasi mangrove hanya fokus terhadap } \\
\text { penguatan perikanan saja? }\end{array}$ \\
\hline & & 5 & $\begin{array}{l}\text { Sampai sejauh mana fokus dari area } \\
\text { perlindungan terhadap habitat mangrove }\end{array}$ \\
\hline \multirow[t]{5}{*}{ Perikanan Tangkap } & & 6 & $\begin{array}{l}\text { Seberapa besar kontribusi perikanan } \\
\text { terhadap dan Budidaya konsumsi per kapita }\end{array}$ \\
\hline & & 7 & $\begin{array}{l}\text { Berapa rerata tangkapan ikan (dalam } \mathrm{kg} \text { ) } \\
\text { per hari per orang }\end{array}$ \\
\hline & & 8 & $\begin{array}{l}\text { Apakah rencana pengelolaan sumberdaya } \\
\text { perikanan sudah efektif }\end{array}$ \\
\hline & & 9 & $\begin{array}{l}\text { Bagaimana rarata pengalaman menangkap } \\
\text { ikan yang dimiliki setiap nelayan }\end{array}$ \\
\hline & & 10 & $\begin{array}{l}\text { Apakah menangkap ikan merupakan satu- } \\
\text { satunya mata pencaharian? }\end{array}$ \\
\hline Integritas di Pesisir & & 11 & $\begin{array}{l}\text { Seberapa banyak erosi lahan yang terjadi } \\
\text { dalam } 30 \text { tahun terakhir? }\end{array}$ \\
\hline \multirow[t]{2}{*}{ Aktifitas Manusia } & Hunian manusia & 12 & $\begin{array}{l}\text { Seberapa besar penyimpangan pola } \\
\text { penggunaan lahan yang sekarang dengan } \\
\text { rencana penggunaan lahan }\end{array}$ \\
\hline & Edukasi & 13 & $\begin{array}{l}\text { Bagaimana populasi orang dewasa dengan } \\
\text { tingkat pendidikan kurang dari } 10 \text { tahun }\end{array}$ \\
\hline
\end{tabular}


Tabel 3.

Skoring pada penilaian kriteria sensitifitas dan kapasitas adaptif lahan mangrove

\begin{tabular}{lll}
\hline \multicolumn{3}{c}{ Scoring } \\
\hline Low (1-2) & Medium (3-4) & High (5) \\
\hline
\end{tabular}

\section{Matriks Analisis}

Matrik analisis dalam Tabel 4. Memberikan gambaran hubungan antara sensitifitas dengan kapasitas adaptif lahan mangrove pada area studi.

\section{HASIL DAN PEMBAHASAN}

\section{Kondisi Mangrove}

Hasil pengamatan mangrove di pesisir pantai Ciletuh Palabuhan Ratu, terdapat 6 jenis mangrove yaitu, Rhizophora mucronata, Avicenia marina, Avicenia alba, Bruguera gimnorhiza, Soneratia alba, dan Ceriops tagal. Adapun hasil pengukuran diamater lingkar batang mangrove pada lokasi pengamatan sangat bervariasi berkisar $9-130 \mathrm{~cm}$ dengan nilai ratarata $23-36 \mathrm{~cm}$.

Pertumbuhan mangrove dipengaruhi oleh masuknya air tawar dan pasokan nutrient dan stabilitas substrat. Pada pesisir pantai Ciletuh Palabuhan Ratu terjadinya kompetisi dalam memperoleh unsur hara dan matahari, sehingga kerapatan mangrove terlihat berbeda. Kerapatan mangrove Pada pesisir pantai Ciletuh Palabuhan Ratu 100 - 1600 ind/ha. Kerapatan/ densitas terendah terdapat pada area dimana dominasi jenis mangrove Sonerratia Alba, sedangkan kerapatan tertinggi pada area domnasi jenis mangrove Rhizophora Mucronata.

Substrat tanah berpasir dan berlumpur menyebabkan pertumbuhan jenis $R$. Mucronata beradaptasi dengan lingkungannya sehingga penyebaran bijinya dapat mudah tumbuh dan berkembang di lokasi penelitian. Hal ini disebabkan dari bentuk propagul yang besar, memanjang dan dapat disebarkan oleh arus secara lebih luas serta memiliki cadangan makanan lebih banyak sehingga kesempatan hidup lebih tinggi, serta jenis S. Alba memiliki buah berbentuk bulat dan besar dengan banyak biji, sehingga memiliki kemungkinan hidup lebih tinggi.

Indeks kemerataan jenis (E) berfungsi untuk mengetahui kemerataan setiap jenis mangrove dalam komunitas pada stasiun pengamatan. Kemerataan jenis memiliki nilai indicator $E=1$ dan jika nilai indikatornya $\geq 1$ maka dapat digunakan sebagai indikator adanya gejala dominansi diantara tiap jenis dalam komunitas. Pada stasiun pengamatan nilai indeks kemerataan mendekati 0 , sehingga bisa dikatakan tidak adanya yang mendominasi pada stasiun pengamatan, (tabel 5) (Barbour et al., 1987).

Indeks keragaman jenis $\left(\mathrm{H}^{\prime}\right)$ memiliki nilai $0-7$, jika keragaman jenis $\leq 2$ dinyatakan sedang apabila beriksar 2-4 dan apabila lebih besar dari 4 dinyatakan tinggi. Pada stasiun pengamatan indeks keragaman jenis memiliki nilai $(-0.17)$ sampai $(-0.35)$, keragaman pada daerah pengamatan ini tergolong rendah, dikarenakan nilai dari tiap jenis mangrove mendekati nol.

Nilai indeks dominasi mendekati 1 apabila komunitas didominasi oleh jenis atau spesies tertentudan jika indeks dominasi mendekati nol (0) maka tidak ada jenis atau spesies yang mendominasi (Odum, 1971). Pada stasiun pengamatan menghasilkan nilai tertinggi 0,06 pada jenis S. Alba, hasil ini terlihat bahwa seluruh jenis mangrove mendekati 0 sehingga tidak ada jenis yang mendominasi.

Hasil perhitungan kerapatan relatif, frekuensi

Tabel 4.

Matriks analisis indeks kerentanan

\begin{tabular}{llllll}
\hline Indeks Kerentanan & & \multicolumn{4}{c}{ Sensitivity } \\
\cline { 3 - 6 } & & $\mathrm{L}(\mathbf{1})$ & $\mathbf{M}(\mathbf{2})$ & $\mathrm{H}(\mathbf{3})$ & $\mathrm{E}(\mathbf{4})$ \\
\hline Adaptive Capacity & $\mathrm{L}(1)$ & $\mathrm{LL}$ & $\mathrm{ML}$ & $\mathrm{HL}$ & $\mathrm{EL}$ \\
& $\mathrm{M}(2)$ & $\mathrm{LM}$ & $\mathrm{MM}$ & $\mathrm{HM}$ & $\mathrm{EM}$ \\
& $\mathrm{H}(3)$ & $\mathrm{LH}$ & $\mathrm{MH}$ & $\mathrm{HH}$ & $\mathrm{EH}$ \\
& $\mathrm{E}(4)$ & $\mathrm{LE}$ & $\mathrm{ME}$ & $\mathrm{HE}$ & $\mathrm{EE}$ \\
\hline
\end{tabular}

Catatan:

- Low (Rendah) adalah rata-rata $1<1.75$

- Moderate (Menengah) adalah rata-rata $1.75<1<=2.5$

- High (Tinggi) adalah rata-rata $2.5<\mathrm{I}<=3.25$

- Ekstrim adalah $\mathrm{I}<3.25$ 
Tabel 5 .

Indeks kemerataan (E), Indeks Keragaman (H”), Indeks Dominasi (D)

\begin{tabular}{llll}
\hline Jenis Mangrove & E & H" & D \\
\hline Bruguera Gymnorhisa & $-0,175$ & $-0,31$ & 0,04 \\
Avicenia Alba & $-0,175$ & $-0,31$ & 0,04 \\
Rhizophora Mucronata & $-0,175$ & $-0,31$ & 0,04 \\
Ceriops Tagal & $-0,145$ & $-0,26$ & 0,02 \\
Soneratia Alba & $-0,193$ & $-0,35$ & 0,06 \\
Avicenia Marina & $-0,097$ & $-0,17$ & 0,00 \\
\hline
\end{tabular}

relatif, penutupan jenis dan Indeks Nilai Penting setiap jenis mangrove pada pesisir pantai Ciletuh Palabuhan Ratu memiliki kerapatan relatif sebesar 29,5\% pada jenis B. Gymnorhisa A. Alba 25,7\%, R. mucronata $17,5 \%$, C. Tagal 14,8\%, S. Alba 9,3\% dan A. Marina $3,3 \%$. Perhitungan Frekuensi relatif pada pesisir pantai Ciletuh Palabuhan Ratu menghasilkan nilai yang sama pada tiga jenis mangrove yaitu $B$. Gymnorhisa A. Alba R. mucronata dengan nilai $18,750 \%$, kemudian $C$. Tagal $12,500 \%$, S. Alba 25,000\%, A. Marina 6,250\%, kesamaan nilai pada tiga jenis mangrove ini terlihat dari lingkungan yang selalu tergenang dan substrat yang mendukung sehingga sangat memungkinkan untuk tumbuh mangrove jenis B. Gymnorhisa A. Alba R. mucronata Nilai penutupan relatif tertinggi yaitu pada jenis $A$. Alba $42,55 \%$ dan terendah pada jenis $A$. Marina 6,85\% (Tabel 6).

Indeks Nilai Penting (INP) antara 0-300 menunjukanketerwakilanjenis mangroveyang berperan dalam ekosistem. INP pada stasiun pengamatan yang terendah adalah pada jenis mangrove $A$. Marina dan nilai tertinggi pada jenis mangrove $A$. Alba. Nilai INP mangrove yang tinggi bergantung pada nilai kerapatan jenis, frekuensi jenis dan luas penutupan jenis mangrove, semakin besar nilai dari tiga parameter ini, maka nilai INP akan semakin besar.

Hasil INP ini dapat memberikan gambaran bahwa jenis mangrove dengan nilai yang tinggi pada pesisir

Tabel 6 .

Nilai Penting Pada pesisir pantai Ciletuh Palabuhan Ratu

\begin{tabular}{llllllll}
\hline Jenis Mangrove & Di & Rdi & Fi & Rfi & Ci & Rci & INP \\
\hline B. Gymnorhisa & 200,0 & 29,5 & 0,375 & 18,750 & 61271 & 7,93 & 56,2 \\
A. Alba & 174,1 & 25,7 & 0,375 & 18,750 & 328711 & 42,55 & 87,0 \\
R. mucronata & 118,5 & 17,5 & 0,375 & 18,750 & 67461 & 8,73 & 45,0 \\
C. Tagal & 100,0 & 14,8 & 0,250 & 12,500 & 92679 & 12,00 & 39,3 \\
S. Alba & 63,0 & 9,3 & 0,500 & 25,000 & 169548 & 21,95 & 56,2 \\
A. Marina & 22,2 & 3,3 & 0,125 & 6,250 & 52921 & 6,85 & 16,4 \\
\hline
\end{tabular}

Tabel 7.

Hasil penilaian sensitifitas untuk masing-masing area studi

\begin{tabular}{lllll}
\hline \multirow{2}{*}{ Sensitifitas } & Kriteria & \multicolumn{2}{c}{$\begin{array}{c}\text { Status Kerentanan } \\
\text { tiap Kriteria }\end{array}$} \\
\cline { 3 - 5 } & & $\begin{array}{c}\text { Sungai Manra } \\
\text { Ciletuh Jaya }\end{array}$ \\
\hline Habitat Mangrove & Sebaran dan Jenis & 1 & 3 & 1 \\
& & 2 & 3 & 2 \\
\cline { 2 - 5 } & Kesehatan hutan & 3 & 3 & 1 \\
mangrove & 4 & 3 & 1 \\
& & 5 & 1 & 1 \\
\cline { 2 - 5 } & Parameter Bio-Fisik & 6 & 3 & 2 \\
& & 7 & 1 & 2 \\
& & 8 & 3 & 3 \\
\hline Sektor Perikanan & 9 & 1 & 1 \\
& Jenis perikanan & 11 & 1 & 1 \\
apa yang beroperasi? & 12 & 1 & 3 \\
& Seberapa penting & 13 & 1 & 3 \\
\cline { 2 - 5 } & kegiatan perikanan & 15 & 3 & 3 \\
terhadap komunitas & & & \\
masyarakat & & & \\
\hline
\end{tabular}


pantai Ciletuh Palabuhan Ratu memberikan peran penting dalam menjaga keberlangsungan komunitas dan lingkungan sekitar.

\section{Kerentanan Ekosistem Mangrove}

Penilaian sensitifitas menunjukkan bahwa habitat mangrove di area Sungai Ciletuh dalam kondisi relatif lebih sensitif dibandingkan dengan mangrove di Manrajaya. Sedangkan untuk kriteria sensitifitas di sektor perikanan, area ekosistem mangrove di Manrajaya menunjukkan hasil yang lebih sensitif daripada Sungai Ciletuh. Hasil penilaian sensitifitas di kedua area mangrove Kabupaten Sukabumi ini dapat dilihat dalam Tabel 7 .

Penilaian kapasitas adaptif menunjukkan bahwa habitat mangrove di area Sungai Ciletuh memiliki kapasitas adaptif yang relatif lebih tinggi dibandingkan dengan mangrove di Manrajaya. Hasil penilaian kapasitas adaptif untuk kedua area mangrove Kabupaten Sukabumi ini dapat dilihat dalam Tabel 8.

Penilaian indeks kerentanan dilakukan dengan menggabungkan nilai sensitifitas dan kapasitas adaptif di kedua area lahan mangrove. Hasilnya adalah area mangrove Sungai Ciletuh masuk kedalam kategori kerentanan menengah-tengah (MM). Area mangrove Manrajaya masuk kedalam kategori Menengah-rendah
(ML). Hasil penilaian indeks kerentanan untuk kedua area mangrove Kabupaten Sukabumi ini dapat dilihat dalam Tabel 9.

\section{KESIMPULAN}

Area mangrove di Sungai Ciletuh dan Manrajaya memiliki tingkat kerentanan menengah. Sensitifitas dan kapasitas adaptif di Sungai Ciletuh lebih tinggi menunjukkan bahwa wilayah tersebut lebih rentan daripada Manrajaya. Hal ini disebabkan oleh karena area mangrove di Manrajaya telah memiliki sistem kelembagaan pengelola untuk ekowisata mangrove. Kedua penulis adalah kontributor utama.

\section{PERSANTUNAN}

Terimakasih kepada Drs. Riyanto Basuki, M.Si sebagai Kepala Pusat Riset Kelautan, Bpk. Triyono, S.Si, MT sebagai Kepala Bidang Riset Mitigasi, Adaptasi dan Konservasi Pusriskel-BRSDM KP. Juga kepada tim Editor dan reviewer Jurnal Segara, serta seluruh pihak yang telah membantu selesainya penelitian ini. Semoga Tuhan YME memberikan balasan terbaik pada bapak/ibu semuanya.

Tabel 8.

Hasil penilaian kapasitas adaptif untuk masing-masing area studi

\begin{tabular}{|c|c|c|c|c|}
\hline \multirow[t]{2}{*}{ Adaptif Capacity } & \multirow[t]{2}{*}{ Kriteria } & & \multicolumn{2}{|c|}{$\begin{array}{l}\text { Status Kerentanan } \\
\text { tiap Kriteria }\end{array}$} \\
\hline & & & $\begin{array}{l}\text { Sungai } \\
\text { Ciletuh }\end{array}$ & $\begin{array}{l}\text { Manra } \\
\text { Ciletuh }\end{array}$ \\
\hline Tingkat Pengelolaan & Upaya pemulihan habitat & 1 & 3 & 1 \\
\hline \multirow[t]{4}{*}{ Mangrove } & $\begin{array}{l}\text { Tingkat Pemanfaatan } \\
\text { Mangrove }\end{array}$ & 2 & 3 & 1 \\
\hline & $\begin{array}{l}\text { Penetapan Kawasan } \\
\text { Konservasi Mangrove }\end{array}$ & 3 & 3 & 1 \\
\hline & & 4 & 2 & 2 \\
\hline & & 5 & 2 & 1 \\
\hline Sektor Perikanan & Perikanan Tangkap & 6 & 3 & 3 \\
\hline \multirow[t]{4}{*}{ Tangkap dan Budidaya } & dan Budidaya & 7 & 2 & 2 \\
\hline & & 8 & 2 & 1 \\
\hline & & 9 & 3 & 3 \\
\hline & & 10 & 3 & 3 \\
\hline Integritas di Pesisir & Erosi Pantai & 11 & 2 & 2 \\
\hline \multirow[t]{2}{*}{ Aktifitas Manusia } & Hunian manusia & 12 & 1 & 1 \\
\hline & Edukasi & 13 & 1 & 1 \\
\hline
\end{tabular}

Tabel 9.

Indeks kerentanan untuk masing-masing area studi

\begin{tabular}{lll}
\hline Kerentanan & $\begin{array}{l}\text { Sungai } \\
\text { Ciletuh }\end{array}$ & $\begin{array}{l}\text { Manra } \\
\text { Jaya }\end{array}$ \\
\hline Sensitifitas & 2,17 & 1,77 \\
Adaptif Kapasitas & 2,32 & 1,46 \\
\hline Kerentanan per lokasi & $\mathrm{MM}$ & $\mathrm{ML}$ \\
\hline
\end{tabular}




\section{DAFTAR PUSTAKA}

Barbour, M. G., Burk, J. H., \& Pitts, W. D., (1987). Terrestrial Plant Ecology, The Benjamin Cummings Publishing Company, Palo Alto.

Bengen D.G. (2001). Pedoman Teknis Pengenalan dan Pengelolaan Ekosistem Mangrove. Pusat Kajian Sumber daya Pesisir dan Lautan - Institut Pertanian Bogor, Indonesia.

Bossel H. (1999). Indicators for Sustainable Development: Theory, Method, Applications A Report to the Balaton Group, International Institute For Sustainable Development, Canada.

Donato, D.C., Kauffman, J.B., Murdiyarso, D., Kurnianto, S., Stidham, M., \& Kanninen, M. (2012). Mangrove Salah Satu Hutan Terkaya Karbon di Daerah Tropis. Brief CIFOR, 12:1-12.

Djohan, T.S. (2007). Distribusi Hutan Bakau di Laguna Pantai Selatan Yogyakarta. Jurnal Manusia dan Lingkungan, 14(1),15-25.

Farrell A., \& Hart M. (1998), What does sustainability really mean? The search for usefull indicators, Environment, 40(9), 26-31.

Kariada, T.M. \& Andin, I. (2014). Peranan Mangrove sebagai Biofilter Pencemaran Air Wilayah Tambak Bandeng, Semarang. Jurnal Manusia dan Lingkungan, 21(2),188-194.

Kusmana C. (2007). Konsep Pengelolaan Mangrove Yang Rasional. Makalah dipresentasikan pada Kegiatan Sosialisasi Bimbingan Teknis dan Pemantauan Pelaksanaan Rehabilitasi Mangrove di Quality Hotel Jalan Somba Opu No. 235 Makassar, 13 Juni 2007.

Lasibani S.M., \& Eni, K. (2009). Pola Penyebaran Pertumbuhan "Propagul" Mangrove Rhizophoraceae di Kawasan Pesisir Sumatera Barat. Jurnal Mangrove dan Pesisir, 10(1), 33-38.

MERF. (2013). Vulnerability assessment tools for coastal ecosystems: A guidebook. Quezon City: Marine Environment and Resources Foundation Inc.

Noor, R., Khazali Y. M., \& Suryadiputra I.N.N. (1999). Panduan Pengenalan Mangrove di Indonesia. PHKA/WI-IP, Bogor.

Odum E.P. (1971). Fundamentals of Ecology, W.B. Saunders Co., Philadelphia.
Ramdhan M., Husrin S., Sudirman N., \& Altanto T., (2012), Pemetaan Indeks Kerentanan Pesisir Terhadap Perubahan Iklim Di Sumatera Barat Dan Sekitarnya, Jurnal Segara, 8 (2), 107-115 
Saenger, P., Hegerl, E.J., \& Davie, J.D.S. (1983). Global Status of Mangrove Ecosystems. IUCN Commission on Ecology Papers No. 3, 88 hal.

Saparinto. (2007), Pendayagunaan Ekosistem Mangrove, PT. Dahara Prize, Semarang.

Schröter, D., Wolfgang Cramer, W., Leemans, R., Prentice, I.C., Araújo, M.B., Arnell, N.W., Bondeau, A., Bugmann, H., Carter, T.R., Gracia, C.A., Vega-Leinert, A.C.D.L., Erhard, M., Ewert, F., Glendining, M., House, J.I., Kankaanpää, S., Klein, R.J.T., Lavorel, S., Lindner, M., Metzger, M.J., Meyer, J., Mitchell, T.D., Reginster, I., Rounsevell, M., Sabaté, S., Sitch, S., Ben Smith, B., Smith, J., Pete Smith, P., Sykes, M.T., Thonicke, K., Thuiller, W., Tuck, G., Zaehle, S., \& Zier, B., (2005), Ecosystem service supply and vulnerability to global change in Europe, Science 310, 1333-1337.

SOPAC (South Pacific Applied Geoscience Commission). (2005). Building resilience in SIDS. The Environmental Vulnerability Index (EVI) 2005. SOPAC Technical Report (Suva, Fiji Islands).

Sudiarta, M. (2006). Ekowisata Hutan Mangrove : Wahana Pelestarian Alam dan Pendidikan Lingkungan. Jurnal Manajemen Pariwisata, 5(1):1-25.

Supriharyono, (2009). Konservasi Ekosistem Sumber daya Hayati di Wilayah Pesisir dan Laut Tropis. Pustaka Pelajar. Yogyakarta

Supriyanto, Indriyanto., \& Bintoro, A. (2014). Inventarisasi Jenis Tumbuhan Obat di HutanMangrove Desa Margasari Kecamatan Labuhan Maringgai Lampung Timur. JurnaSylva Lestari, 2(1):67-75.

Turner II, B. L., Kasperson, R.E., Matson, P.A., McCarthy, J.J., Corell, R.W., Christensen, L., Eckley, N., Kasperson, J.X., Luers, A., Martello, M.L., Polsky, C., Pulsipher, A., \& Schiller, A., (2003), A framework for vulnerability analysis in sustainability science, PNAS, 100 (14), 80748079.

UNISDR, (2005). Hyogo Framework for Action 20052015: Building the Resilience of Nations and Communities to Disasters. Geneva, Switzerland UNISDR. Available at http://www.unisdr.org/eng/ hfa/hfa.htm; accessed on 27 August 2019.

Utomo, B., Budiastuti S., \& Muryani C. (2017). Strategi Pengelolaan Hutan Mangrove Di Desa Tanggul Tlare Kecamatan Kedung Kabupaten Jepara. 